\title{
Uncertain Systems Order Reduction by Aggregation Method
}

\author{
Bogapurapu Gayatri ${ }^{1}$, Kalyana Kiran Kumar ${ }^{2}$, Akella Venkata Santosh Lakshmi ${ }^{3}$, \\ Vyakaranam Sai Karteek ${ }^{4}$ \\ ${ }^{1,3,4}$ Department of Electrical and Electronics Engineering, PG Scholar, VITS College of Engineering \\ ${ }^{2}$ Professor and Head of EEE Department, VITS College of Engineering
}

\begin{tabular}{|c|c|}
\hline Article Info & ABSTRACT \\
\hline Article history: & \multirow{5}{*}{$\begin{array}{l}\text { In the field of control engineering, approximating the higher-order system } \\
\text { with its reduced model copes with more intricateproblems. These complex } \\
\text { problems are addressed due to the usage of computing technologies and } \\
\text { advanced algorithms. Reduction techniques enable the system from higher- } \\
\text { order to lower-order form retaining the properties of former even after } \\
\text { reduction. This document renders a method for demotion of uncertain } \\
\text { systems based on State Space Analysis. Numerical examples are illustrated to } \\
\text { show the accuracy of the proposed method. }\end{array}$} \\
\hline Received Jun 2, 2016 & \\
\hline Revised Aug 10, 2016 & \\
\hline Accepted Aug 18, 2016 & \\
\hline Keyword: & \\
\hline
\end{tabular}

Aggregation method

Interval systems

Kharitonov's theorem

Order reduction

Stability

Copyright (c) 2017 Institute of Advanced Engineering and Science. All rights reserved.

\section{Corresponding Author:}

Kalyana Kiran Kumar,

Professor and Head of EEE Department,

VITS College of Engineering,

Sontyam, Anandapuram,

Visakhapatnam, Andhra Pradesh, India.

Email: kirankalyana1@gmail.com

\section{INTRODUCTION}

In present time'sengineers and scientists are often with the analysis, design and synthesis of real time problems. The primary step to be followed is to develop a mathematical model which is an equivalent representation for the real problem.

In general, these mathematical models possessedwith large dimensions and are named as large-scale systems. On the other hand, a highly detailed model would lead to a great deal of unnecessary complications. Hence forth a mechanism being applied to bring a compromisebetween the reduced model and original system so as to preserve the properties of the original system in its reduced model. The large-scale systems model reduction has two approaches like Time domain and Frequency domain. In frequency domain, continued fraction expansion method has low computational efforts and is applicable to multivariable systems, but the major drawback in this method is it does not preserve the stability after reduction [1]. Similarly in Time domain approach using routh approximation method, the steady state condition of the system is preserved, but it does not preserve the transient state of system [2].

Reduction of continuous interval systems by routh approximation [3], and discrete interval systems by retention of dominant poles and direct series expansion method [4]. Based on study of stability and transient analysis of interval systems many methods have been proposed by the researchers on interval systems [5-9]. In this note the author extends the paper by reduction of interval systems in to state space form of realization using 'Aggregation method'.

The outline of this note consists of four sections. In Section 2, Problem Statement will be is discussed. In Section 3, Procedural Steps for the proposed technique is explained. In Section 4, Error Analysis is done. In Section 5, the performance of the proposed method is shownby a numerical example. In 
Section 6, comparisons between the proposed and other methods are illustrated. At last, a conclusion is stated in Section 7.

\section{PROBLEM STATEMENT}

Consider an original linear time invariant uncertain system in Controllable Canonical Form:

$$
\sum:\left\{\begin{array}{c}
\dot{x}(t)=A_{n \times n} x(t)+B_{n \times m} u(t) \\
y(t)=C_{q \times n} x(t)+D_{q \times m} u(t)
\end{array} \Leftrightarrow \sum:=\left[\begin{array}{ccc}
A_{n \times n} & \vdots & B_{n \times m} \\
\cdots \cdots & \cdots & \cdots \cdots \\
C_{q \times n} & \vdots & D_{q \times m}
\end{array}\right]\right.
$$

where

$$
\begin{aligned}
& \mathrm{A}_{\mathrm{n} \times \mathrm{n}}=\left[\begin{array}{cccc}
0 & 1 & \ldots & 0 \\
\vdots & \vdots & \ldots & \vdots \\
0 & 0 & \ldots & 1 \\
-\left[\mathrm{w}_{0}^{-}, \mathrm{w}_{0}^{+}\right] & -\left[\mathrm{w}_{1}^{-}, \mathrm{w}_{1}^{+}\right] & \ldots & -\left[\mathrm{w}_{\mathrm{n}}^{-}, \mathrm{w}_{\mathrm{n}}^{+}\right]
\end{array}\right] \\
& \mathrm{B}_{\mathrm{n} \times \mathrm{m}}=\left[\begin{array}{c}
0 \\
\vdots \\
\vdots \\
\vdots \\
\vdots \\
0 \\
1
\end{array}\right] \\
& \mathrm{C}_{\mathrm{q} \times \mathrm{n}}=\left[\left[\mathrm{z}_{0}^{-}, \mathrm{z}_{0}^{+}\right] \quad\left[\mathrm{z}_{1}^{-}, \mathrm{z}_{1}^{+}\right] \quad \cdots \quad\left[\mathrm{z}_{\mathrm{n}-1}^{-}, \mathrm{z}_{\mathrm{n}-1}^{+}\right]\right]
\end{aligned}
$$

$n=$ no. of state variables; $m=$ no. of inputs variables; $q=$ no. of outputs variables

The Corresponding demoted order model of an uncertain system is represented in Controllable Canonical Form (CCF) as follows:

$$
\sum_{\mathrm{r}}:\left\{\begin{array}{c}
\dot{\mathrm{x}}_{\mathrm{r}}(\mathrm{t})=\mathrm{A}_{\mathrm{r}} \mathrm{x}_{\mathrm{r}}(\mathrm{t})+\mathrm{B}_{\mathrm{r}} \mathrm{u}(\mathrm{t}) \\
\mathrm{y}_{\mathrm{r}}(\mathrm{t})=\mathrm{C}_{\mathrm{r}} \mathrm{x}_{\mathrm{r}}(\mathrm{t})+\mathrm{D}_{\mathrm{r}} \mathrm{u}(\mathrm{t})
\end{array} \Leftrightarrow \sum:=\left[\begin{array}{ccc}
\mathrm{A}_{\mathrm{r}} & \vdots & \mathrm{B}_{\mathrm{r}} \\
\cdots \cdots & \cdots & \cdots \cdots \\
\mathrm{C}_{\mathrm{r}} & \vdots & \mathrm{D}_{\mathrm{r}}
\end{array}\right]\right.
$$

where

$$
\begin{aligned}
& \mathrm{A}_{\mathrm{r}}=\left[\begin{array}{cccc}
0 & 1 & \ldots & 0 \\
\vdots & \vdots & \cdots & \vdots \\
0 & 0 & \ldots & 1 \\
-\left[\mathrm{x}_{0}^{-}, \mathrm{x}_{0}^{+}\right] & -\left[\mathrm{x}_{1}^{-}, \mathrm{x}_{1}^{+}\right] & \ldots & -\left[\mathrm{x}_{\mathrm{r}}^{-}, \mathrm{x}_{\mathrm{r}}^{+}\right]
\end{array}\right] \\
& \mathrm{B}_{\mathrm{r}}=\left[\begin{array}{c}
0 \\
\vdots \\
\vdots \\
\vdots \\
\vdots \\
0 \\
1
\end{array}\right] \\
& \mathrm{C}_{\mathrm{r}}=\left[\begin{array}{llll}
{\left[\mathrm{y}_{0}^{-}, \mathrm{y}_{0}^{+}\right]} & {\left[\mathrm{y}_{1}^{-}, \mathrm{y}_{1}^{+}\right]} & \cdots & \left.\left[\mathrm{y}_{\mathrm{r}-1}^{-}, \mathrm{y}_{\mathrm{r}-1}^{+}\right]\right]
\end{array}\right.
\end{aligned}
$$

$r=$ reduced order

Hansen. E [10] explainedthe fundamental arithmetic rules for an interval plant as follows: Addition:

$$
[i, j]+[o, v]=[i+o, j+v]
$$


Subtraction:

$$
[i, j]-[o, v]=[i-o, j-v]
$$

Multiplication:

$$
[i, j] \times[o, v]=[\min (i o, i v, j o, j v), \max (i o, i v, j o, j v)]
$$

Division:

$$
\frac{[i, j]}{[0, v]}=[i, j] \times\left[\frac{1}{0}, \frac{1}{v}\right]
$$

\section{PROCEDURAL STEPS}

Step 1: The equivalent transfer function for the original uncertain plant expressed in Equation 1 is:

$$
Q(s)=\frac{N(s)}{D(s)}
$$

where

$$
\begin{aligned}
& \mathrm{D}(\mathrm{s})=\mathrm{s}^{\mathrm{n}}+\sum_{\mathrm{k}=1}^{\mathrm{n}-1} \mathrm{w}_{\mathrm{k}} * \mathrm{~s}^{\mathrm{k}}, \quad \mathrm{w}_{\mathrm{k}}=\left[\mathrm{w}_{\mathrm{k}}^{-}, \mathrm{w}_{\mathrm{k}}^{+}\right] \\
& \mathrm{N}(\mathrm{s})=\sum_{\mathrm{k}=0}^{\mathrm{n}-1} \mathrm{z}_{\mathrm{k}} * \mathrm{~s}^{\mathrm{k}}, \mathrm{z}_{\mathrm{k}}=\left[\mathrm{z}_{\mathrm{k}}^{-}, \mathrm{z}_{\mathrm{k}}^{+}\right]
\end{aligned}
$$

Step 2: The above uncertain system is converted to four fixed transfer functions which carries the coefficients of Equation 7 this can be represented in its general form using Kharitonov's theorem [3]

$$
E_{p}(s)=\frac{\sum_{e=0}^{n-1} N_{p_{e}} s^{e}}{\sum_{f=0}^{n} D_{p_{f}} s^{f}}
$$

where

$$
\mathrm{e} \leq \mathrm{n}-1 ; \mathrm{f} \leq \mathrm{n} ; \mathrm{p}=1,2,3,4
$$

Step 3: The above four transfer functions are transformed into four fixed state models:

$\sum_{\mathrm{p} / \mathrm{n}}:=\left[\begin{array}{ccc}\mathrm{A}_{\mathrm{p} / \mathrm{n} \times \mathrm{n}} & \vdots & \mathrm{B}_{\mathrm{p} / \mathrm{n} \times \mathrm{m}} \\ \cdots \cdots & \cdots & \cdots \cdots \\ \mathrm{C}_{\mathrm{p} / \mathrm{q} \times \mathrm{n}} & \vdots & \mathrm{D}_{\mathrm{p} / \mathrm{q} \times \mathrm{m}}\end{array}\right]$

$\mathrm{p}=1,2,3,4$

Step 4: Evaluate the Eigen values for the obtained four fixed state models represented in Equation 9 individually

Step 5: Calculate the modal matrix $\left(M_{p}\right)$ is calculated for each individual state model:

$$
M_{p}=\left[\begin{array}{ll}
M_{p_{1}} & M_{p_{2}} \\
M_{p_{3}} & M_{p_{4}}
\end{array}\right]
$$

where

$\mathrm{p}=1,2,3,4 ; \mathrm{M}_{\mathrm{p}_{1}}=(\mathrm{r} \times \mathrm{r})$ and $\mathrm{M}_{\mathrm{p}_{4}}=(\mathrm{n}-\mathrm{r} \times \mathrm{n}-\mathrm{r})$

Step 6: Now the inverse of modal matrix $\left(\overline{\mathrm{M}}_{\mathrm{p}}\right)$ is to be evaluated from 
$\overline{\mathrm{M}}_{\mathrm{p}}=\left[\begin{array}{ll}\overline{\mathrm{M}}_{\mathrm{p}_{1}} & \overline{\mathrm{M}}_{\mathrm{p}_{2}} \\ \overline{\mathrm{M}}_{\mathrm{p}_{3}} & \overline{\mathrm{M}}_{\mathrm{p}_{4}}\end{array}\right]$

where

$\mathrm{p}=1,2,3,4 ; \overline{\mathrm{M}}_{\mathrm{p}_{1}}=(\mathrm{r} \times \mathrm{r})$ and $\overline{\mathrm{M}}_{\mathrm{p}_{4}}=(\mathrm{n}-\mathrm{r} \times \mathrm{n}-\mathrm{r})$

Step 7: Obtain the arbitrary matrix $\left(\mathrm{M}_{\mathrm{p}_{0}}\right)$ followed by the Equation below:

$M_{p_{0}}=\left[I_{r}: \mathbf{0}_{r \times(n-r)}\right]$

Step 8: Determine the aggregation matrix ' $\mathrm{K}_{\mathrm{p}}$ ' using the Equation

$\mathrm{K}_{\mathrm{p}}=\mathrm{M}_{\mathrm{p}_{1}} \mathrm{M}_{\mathrm{p}_{0}} \overline{\mathrm{M}}_{\mathrm{p}}$

Step 9: Using the aggregation matrix the four reduced state models are obtained and are represented in generalized form as

$\sum_{p / r}:=\left[\begin{array}{ccc}A_{p / r \times r} & \vdots & B_{p / r \times m} \\ \cdots \cdots & \cdots & \cdots \cdots \\ C_{p / q \times r} & \vdots & D_{p / q \times m}\end{array}\right]$

where

$$
\begin{aligned}
& \mathrm{A}_{\mathrm{p} / \mathrm{r} \times \mathrm{r}}=\mathrm{K}_{\mathrm{p}} \mathrm{A}_{\mathrm{p} / \mathrm{n} \times \mathrm{n}} \mathrm{K}_{\mathrm{p}}^{\mathrm{T}}\left[\mathrm{K}_{\mathrm{p}} \mathrm{K}_{\mathrm{p}}^{\mathrm{T}}\right]^{-1} \\
& \mathrm{~B}_{\mathrm{p} / \mathrm{r} \times \mathrm{m}}=\mathrm{K}_{\mathrm{p}} \mathrm{B}_{\mathrm{p} / \mathrm{n} \times \mathrm{m}} \\
& \mathrm{C}_{\mathrm{p} / \mathrm{q} \times \mathrm{r}}=\mathrm{C}_{\mathrm{p} / \mathrm{q} \times \mathrm{n}} \mathrm{K}_{\mathrm{p}}^{\mathrm{T}}\left[\mathrm{K}_{\mathrm{p}} \mathrm{K}_{\mathrm{p}}^{\mathrm{T}}\right]^{-1} \\
& \mathrm{p}=1,2,3,4 ; \mathrm{r}=\text { order of reduced system }
\end{aligned}
$$

Step 10: The corresponding four reduced $\mathrm{r}^{\text {th }}$ order transfer functions for the above obtained four reduced $\mathrm{r}^{\text {th }}$ order state model expressed in Equation 14 in its general form:

$$
\mathrm{R}_{\mathrm{p}}(\mathrm{s})=\frac{\sum_{\mathrm{g}=0}^{\mathrm{r}-1} \mathrm{y}_{0} \mathrm{p}_{\mathrm{g}} \mathrm{s}}{\sum_{\mathrm{h}=0}^{\mathrm{r}} \mathrm{x}_{0} \mathrm{p}_{\mathrm{h}} \mathrm{s}^{\mathrm{h}}}
$$

where

$\mathrm{g} \leq \mathrm{r}-1 ; \mathrm{h} \leq \mathrm{r} ; \mathrm{p}=1,2,3,4 ; \mathrm{r}=$ order of reduced system

Step 11: Now the equivalent transfer function for reduced interval system is equated below:

$$
\mathrm{R}(\mathrm{s})=\frac{\left[\mathrm{y}_{0}^{-}, \mathrm{y}_{0}^{+}\right]+\left[\mathrm{y}_{1}^{-}, \mathrm{y}_{1}^{+}\right] \mathrm{s}+\cdots \cdots+\left[\mathrm{y}_{\mathrm{r}-1}^{-}, \mathrm{y}_{\mathrm{r}-1}^{+}\right] \mathrm{s}^{\mathrm{r}-1}}{\left[\mathrm{x}_{0}^{-}, \mathrm{x}_{0}^{+}\right]+\left[\mathrm{x}_{1}^{-}, \mathrm{x}_{1}^{+}\right] \mathrm{s}+\cdots \cdots+\left[\mathrm{x}_{\mathrm{r}}^{-}, \mathrm{x}_{\mathrm{r}}^{+}\right] \mathrm{s}^{\mathrm{r}}}
$$
Form $(\mathrm{CCF})$

Step 12: Finally the demoted model of the interval system is expressed in Controllable Canonical

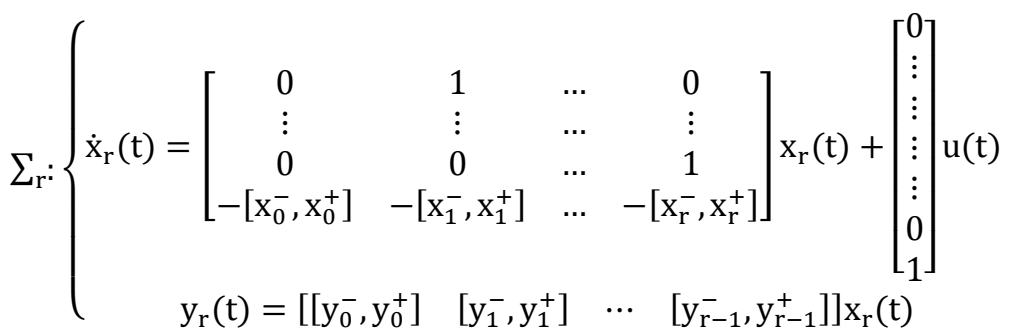




\section{INTEGRAL AND RELATIVE INTEGRAL SQUARE ERROR}

The integral and relative integral square error between transient responses of original and reduced systems is also determined as formulated below:

$$
\begin{aligned}
& \text { Relative ISE }=\int_{0}^{\infty}[q(\mathrm{t})-\mathrm{r}(\mathrm{t})]^{2} \mathrm{dt} / \int_{0}^{\infty}[\mathrm{q}(\mathrm{t})-\mathrm{r}(\infty)]^{2} \mathrm{~d} \\
& \text { ISE }=\int_{0}^{\infty}[\mathrm{q}(\mathrm{t})-\mathrm{r}(\mathrm{t})]^{2} d t
\end{aligned}
$$

where $\mathrm{q}(\mathrm{t})$ and $\mathrm{r}(\mathrm{t})$ are the unit step responses of original $\mathrm{Q}(\mathrm{s})$ and reduced $\mathrm{R}(\mathrm{s})$ systems, $\mathrm{r}(\infty)$ final value of original system

\section{NUMERICAL ILLUSTRATION}

\subsection{Example 1}

Let us consider an interval system having state model as followed below:

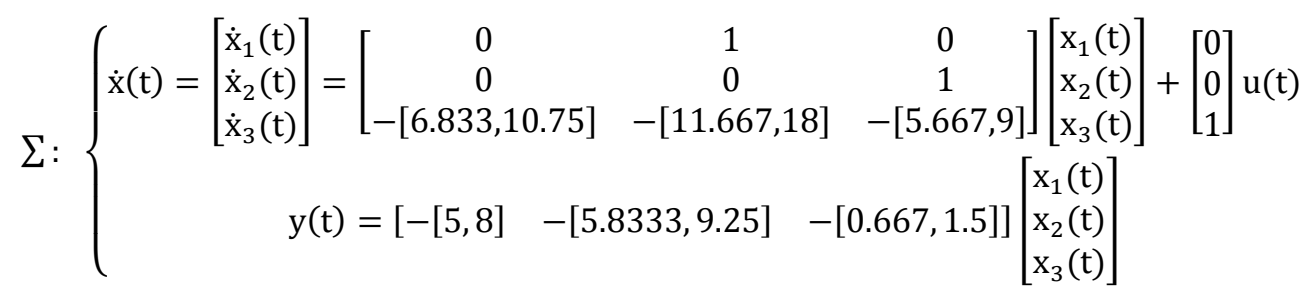

1. The equivalent transfer function of an uncertain is as follows:

$$
\mathrm{Q}(\mathrm{s})=\frac{[0.6667,1.5] \mathrm{s}^{2}+[5.8333,9.25] \mathrm{s}+[5,8]}{[1,1] \mathrm{s}^{3}+[5.667,9] \mathrm{s}^{2}+[11.667,18] \mathrm{s}+[6.8333,10.75]}
$$

2. Evaluate the four $3^{\text {rd }}$ order transfer functions by using Kharitonov's theorem as expressed in Equation (8)

3. The above four transfer functions are converted into four state models by using Equation 9 are:

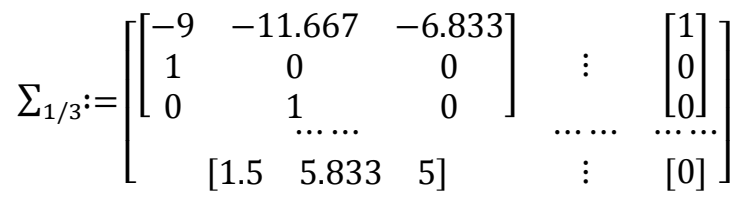

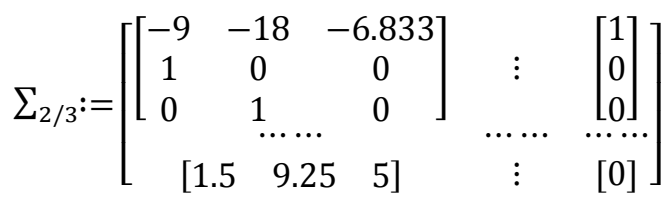

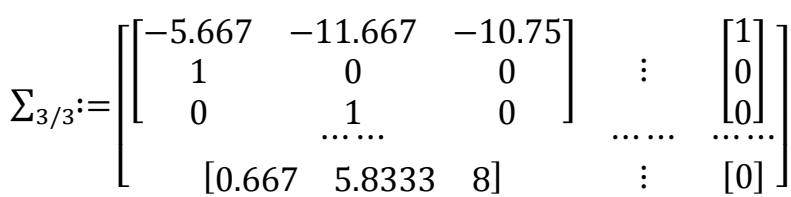

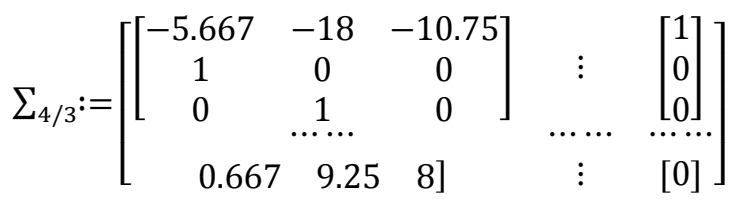

4. Next Eigen values are to be determined individually for the above four state models

5. Then modal matrix, inverse of modal matrix and $\mathrm{M}_{\mathrm{p}_{0}}, \mathrm{~K}_{\mathrm{p}}$ matrices are obtained for the four state models individually by using Equations 10 to 13 
6. Four reduced order state models are obtained from Equation 14 as given below:

$$
\begin{aligned}
& \Sigma_{1 / 2}:=\left[\begin{array}{cccc}
{\left[\begin{array}{cc}
-8.314 & -7.197 \\
1.0001 & 0.0002
\end{array}\right]} & \vdots & {\left[\begin{array}{c}
1.104 \\
0.109
\end{array}\right]} \\
{[0.945} & 8.145] & \vdots & {[0]}
\end{array}\right] \\
& \Sigma_{2 / 2}:=\left[\begin{array}{cccc}
{\left[\begin{array}{cc}
-8.504 & -13.784 \\
0.999 & 0.0002
\end{array}\right]} & \vdots & {\left[\begin{array}{c}
0.9749 \\
0.0505
\end{array}\right]} \\
{[1.0333} & 6.8325] & \vdots & {[0]}
\end{array}\right]
\end{aligned}
$$

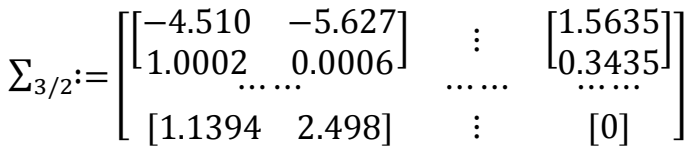

$$
\begin{aligned}
& \sum_{4 / 2}:=\left[\begin{array}{cccc}
{\left[\begin{array}{cc}
-4.9159 & -14.3097 \\
0.9999 & \ldots .0003
\end{array}\right]} & \vdots & {\left[\begin{array}{c}
0.9495 \\
0.0672
\end{array}\right]} \\
{\left[\begin{array}{ll}
0.2666 & 7.3319
\end{array}\right]} & \vdots & {[0]}
\end{array}\right]
\end{aligned}
$$

5. The corresponding demoted order transfer functions are obtained as expressed in Equation 15 using four reduced state models from Equations 25 to 28

6. Thenthe equivalent reduced order transfer function for interval system is obtained as expressed in Equation 16:

$$
\mathrm{R}(\mathrm{s})=\frac{[0.239,2.165] \mathrm{s}+[4.265,9.639]}{[1,1] \mathrm{s}^{2}+[4.509,8.504] \mathrm{s}+[5.626,14.31]}
$$

Under steady state condition $s \rightarrow 0$ then

$$
\mathrm{R}(\mathrm{s})=\frac{[0.2306,2.3923] \mathrm{s}+[4.1157,10.6511]}{[1,1] \mathrm{s}^{2}+[4.509,8.504] \mathrm{s}+[5.626,14.31]}
$$

7. The CCF of the reduced order interval system

$$
\sum_{\mathrm{r}}:\left\{\begin{array}{c}
\dot{\mathrm{x}}_{\mathrm{r}}(\mathrm{t})=\left[\begin{array}{cc}
0 & 1 \\
-[5.626,14.31] & -[4.509,8.504]
\end{array}\right] \mathrm{x}_{\mathrm{r}}(\mathrm{t})+\left[\begin{array}{l}
0 \\
1
\end{array}\right] \mathrm{u}(\mathrm{t}) \\
\mathrm{y}_{\mathrm{r}}(\mathrm{t})=[[4.1157,10.6511] \\
[0.2306,2.3923]] \mathrm{x}_{\mathrm{r}}(\mathrm{t})
\end{array}\right.
$$

Step responses of both original and reduced $3^{\text {rd }}$ order systems are shown in Figure 1 below

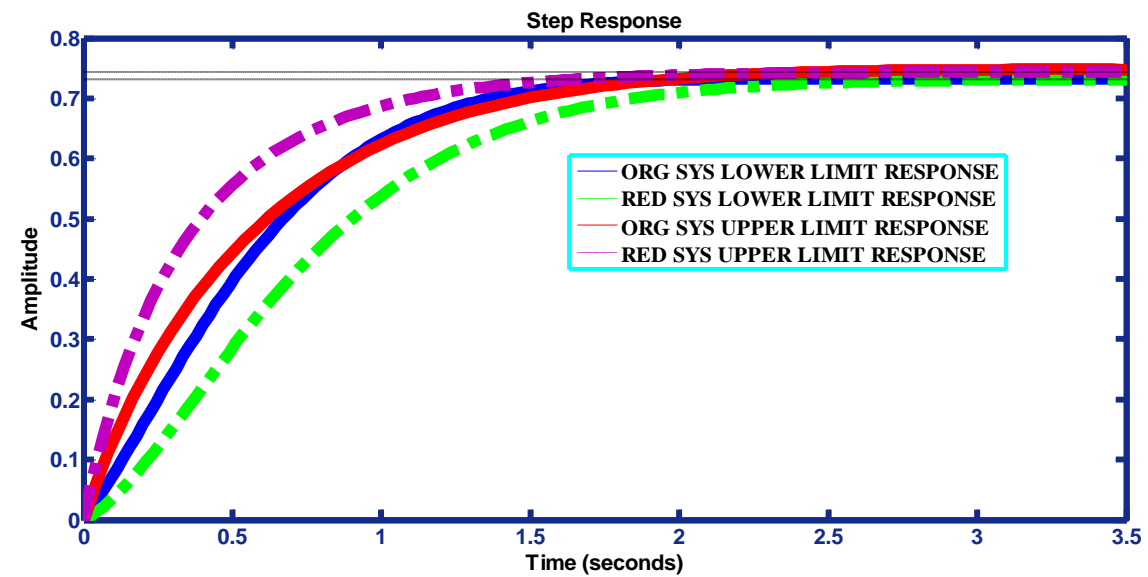

Figure 1. Step Response of Original and Reduced $3^{\text {rd }}$ Order System using Proposed Method 


\section{COMPARSION OF METHODS}

The demoted order models of proposed method are compared with other methods are shown in Figure 2, 3 and 4.

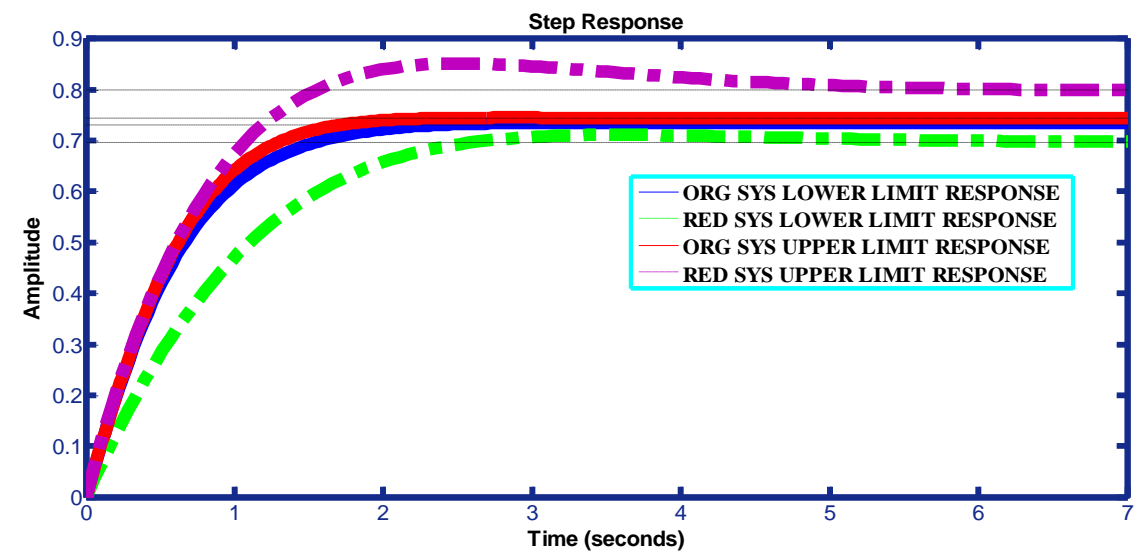

Figure 2. Step Response of Original and Reduced $3^{\text {rd }}$ Order System using Mihailov and Cauer Second Form

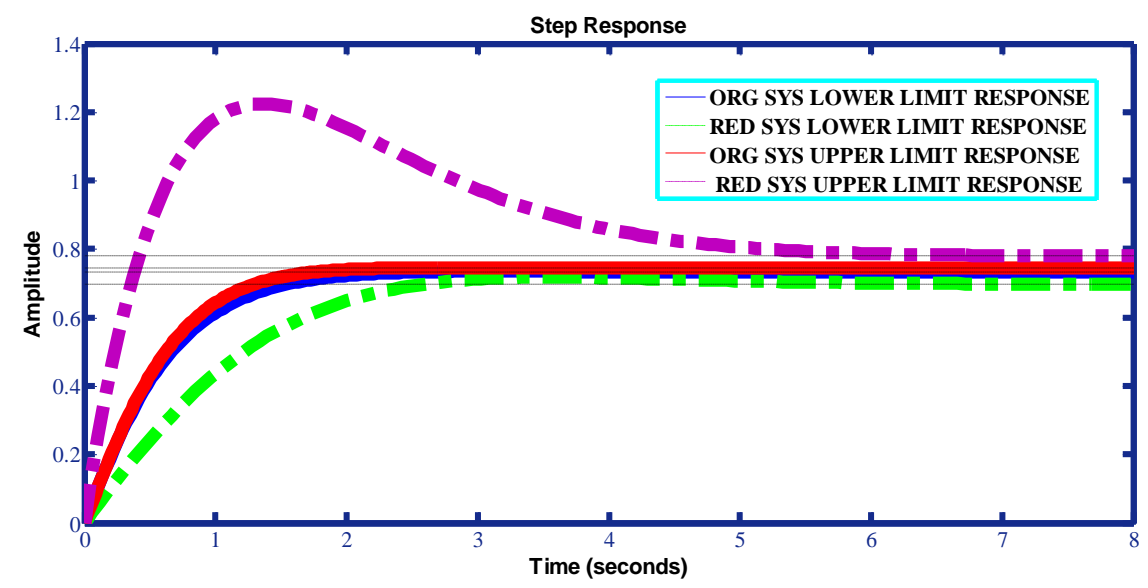

Figure 3. Step Response of Original and REDuced $3^{\text {rd }}$ Order System using Routh and Factor Division Method

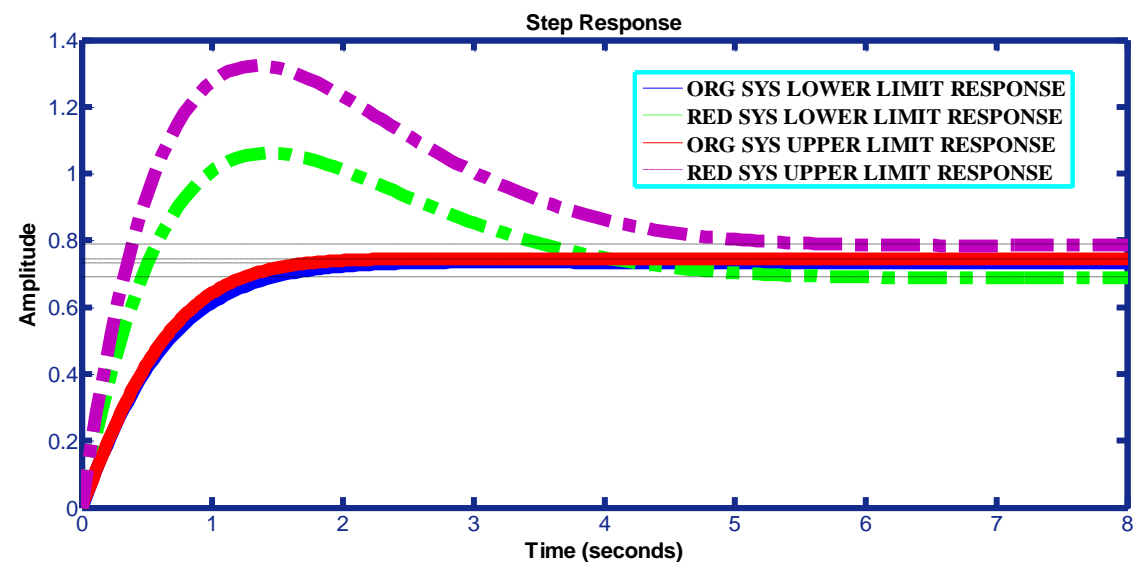

Figure 4. Step Response of Original and Reduced $3^{\text {rd }}$ Order System using Mihailov and Factor Division Method 
Table 1 shows Comparison of Reduced Order Models for $3^{\text {rd }}$ order system.

Table 1. Comparison of Reduced Order Models for $3^{\text {rd }}$ Order System

\begin{tabular}{|c|c|c|c|c|c|c|}
\hline \multirow{2}{*}{ S.no. } & \multirow{2}{*}{ Methods } & \multirow{2}{*}{ Reduced Order Systems } & \multicolumn{2}{|c|}{$\begin{array}{l}\text { Step Response of } \\
\text { Lower Limit }\end{array}$} & \multicolumn{2}{|c|}{$\begin{array}{l}\text { Step Response of } \\
\text { Higher Limit }\end{array}$} \\
\hline & & & $\begin{array}{c}\text { ISE } \\
\text { Values }\end{array}$ & $\begin{array}{l}\text { Relative } \\
\text { ISE } \\
\text { Values }\end{array}$ & $\begin{array}{c}\text { ISE } \\
\text { Values }\end{array}$ & $\begin{array}{l}\text { Relative } \\
\text { ISE } \\
\text { Values }\end{array}$ \\
\hline 1. & $\begin{array}{l}\text { Proposed } \\
\text { Method }\end{array}$ & $\mathrm{R}(\mathrm{s})=\frac{[0.2306,2.3923] \mathrm{s}+[4.1157,10.6511]}{[1,1] \mathrm{s}^{2}+[4.509,8.504] \mathrm{s}+[5.626,14.31]}$ & 0.012 & 0.070 & 0.009 & 0.066 \\
\hline 2. & $\begin{array}{l}\text { Mihailov } \\
\text { and cauer } \\
\text { second } \\
\text { form }\end{array}$ & $\mathrm{R}(\mathrm{s})=\frac{[11.19,20.37] \mathrm{s}+[14.16,16.94]}{[17.1,18.1] \mathrm{s}^{2}+[31.382,33.6] \mathrm{s}+[20.31,21.2]}$ & 0.014 & 0.086 & 0.025 & 0.157 \\
\hline 3. & $\begin{array}{l}\text { Routh and } \\
\text { Factor } \\
\text { Division } \\
\text { Method }\end{array}$ & $\mathrm{R}(\mathrm{s})=\frac{[8.8417,47.0513] \mathrm{s}+[14.3023,16.7805]}{[17,18] \mathrm{s}^{2}+[29.4722,35.7059] \mathrm{s}+[20.5,21.5]}$ & 0.344 & 2.152 & 0.007 & 0.042 \\
\hline 4. & $\begin{array}{l}\text { Mihailov } \\
\text { and Factor } \\
\text { Division } \\
\text { Method }\end{array}$ & $\begin{array}{l}\mathrm{R}(\mathrm{s}) \\
=\frac{[35.6065,49.4454] \mathrm{s}+[14.0331,17.1024]}{[17.0011,18.0007] \mathrm{s}^{2}+[31.3826,33.6111] \mathrm{s}+[20.3061,21.7052]}\end{array}$ & 0.457 & 2.833 & 0.623 & 3.856 \\
\hline
\end{tabular}

\section{CONCLUSION}

To decrease the complexity of the system order reduction is done. In this note the order reduction by proposed method is numerically solved. The proposed method implemented for order reduction represented the uncertain systems in state model. The demoted model obtained by proposed method is compared with other methods, and the ISE \& Relative ISE values of step response are also compared. Hence the proposed method maintains stability with low ISE values compared to other existing methods.

\section{REFERENCES}

[1] L. S. Shieh and M. J. Goldman, "Continued Fraction Expansion and Inversion of cauer third Form," IEEE Trans.On Circuits and systems, vol/issue: CAS-21(3), pp. 341-345, 1974.

[2] M. Chand, "Reducing Model Ordering using Routh Approximation Method," International Journal of Emerging Technology and Advanced Engineering, vol/issue: 4(8), 2014.

[3] Bandyopadhyay B., et al., "Routh pade approximation for interval systems," IEEE Trans Autom Control, vol. 39, pp. 2454-2456, 1994.

[4] C. Younseok, "A note on discrete interval system reduction via retention of dominant poles," Int J Control Autom Syst, vol/issue: 5(2), pp. 208-211, 2007.

[5] Saraswathi G., "A mixed method for order reduction of interval systems," Int Conf IntelAdv. Syst, pp. 1042-1046, 2007.

[6] Ismail O. and Bandyopadhyay B., "Model order reduction of linear interval systems using pade approximation," IEEE Int Symp Circ Syst, 1995.

[7] Singh V. P. and Chandra D., "Routh approximation based model reduction using series expansion of interval systems," IEEE Int Conf Power Control Embed Syst (ICPCES), vol. 1, pp. 1-4, 2010.

[8] Singh V. P. and Chandra D., "Model reduction of discrete interval system using dominant poles retention and direct series expansion method," in Proceedings of the IEEE 5th International power engineering and optimization conference (PEOCO), vol 1. pp. 27-30, 2011.

[9] K. Kumar D, et al.. "Model order reduction of interval systems using modified routh approximation and factor division method," in Proceedings of 35th national system conference (NSC), IIT Bhubaneswar, India, 2011.

[10] Hansen E., "Interval arithmetic in matrix computations," Part I Siam J Numer Anal, pp. 308-320, 1965. 


\section{BIOGRAPHIES OF AUTHORS}

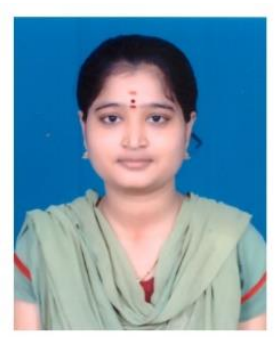

Gayatri Bogapurapu received B.Tech degree in Electrical and Electronics Engineering in the year 2014 from Simhadhri College of Engineering. She is now pursuing M.tech degree in the specialization of Power System Automation and Control in VITS College of Engineering, Visakhapatnam, India.

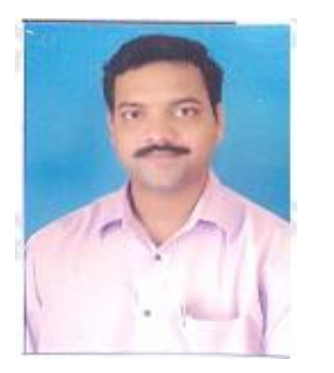

Kiran Kumar Kalyana received B.Tech degree in Electrical and Electronics Engineering in the year 2001 from GMRIT Rajam, M.E degree in the specialization of Control Systems in the year 2004 from AUCE, Andhra University, Ph.D degree in Electrical Engineering from A.U, Visakhapatnam in 2015. His research areas are control systems,interval systems, Non-linear systems, Adaptive control systems. He is a member of ISTE, IAENG(HK), IETE.

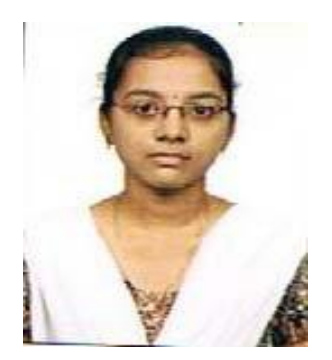

Venkata Santosh Lakshmi Akella received B.Tech degree in Electrical and Electronics Engineering in the year 2013 from Nightingale Engineering College for Women. She is now pursuing M.tech degree in the specialization of Power System Automation and Control in VITS College of Engineering, Visakhapatnam, India.

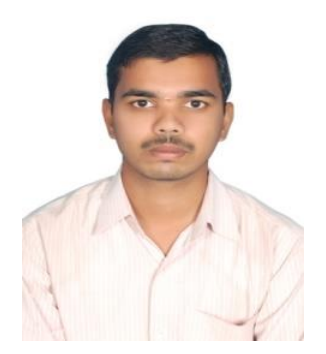

Sai Karteek Vyakaranam received B.Tech degree in Electrical and Electronics Engineering in the year 2014 from Sri Chaitanya College of Engineering. He is now pursuing M.tech degree in the specialization of Power System Automation and Control in VITS College of Engineering, Visakhapatnam, India. 